\title{
Comparative Performance of Wheat Post-Emergence Herbicides In Relation To Their Effect on Wheat Yield
}

\author{
Saad, A. S. A.; E. H. M. Tayeb; M. A. Masoud and R. A. A. Shawer ${ }^{1}$
}

\begin{abstract}
Two field experiments were conducted in a research experimental farm in Rasheed region, Behaira Governorate during two wheat growing seasons of 2007 and 2008 winter to evaluate the performance of certain herbicides namely: bromoxynil-octanoate $\left(\right.$ Brominal $^{\circledR} 24 \%$ EC), tribenuron-methyl (Granstar ${ }^{\circledR} \quad 75 \%$ DF), diflufenican+isoproturon (Panther ${ }^{\circledR} \quad 55 \% \quad$ SC) and florasulam+flumetsulam (Derby ${ }^{\circledR} 17.5 \%$ SC) at rates of $1000 \mathrm{ml}, 8 \mathrm{~g}, 600 \mathrm{ml}$ and $30 \mathrm{ml}$, respectively/feddan. The evaluated herbicides are selected against the broad leaved weeds and therefore they have been used to overcome the most harmful weeds[ wild beet (Beta vulgaris), nettleleaf goosefoot (Chenopodium murale) and toothed bur clover (Medicago hispida)] found in the fields of wheat (Triticum aestivum var. Sakha 61). Furthermore the effect of the evaluated compounds on wheat yield was considered. The data showed that the superior effect was achieved by tribenuron-methyl $\left(\right.$ Granstar $\left.^{\circledR}\right)$. Meanwhile it is also recorded the highest percentage of wheat yield increase, followed by bromoxynil-octanoate $\left(\right.$ Brominal $^{\circledR}$ ), florasulam + flumetsulam $\left(\right.$ Derby $\left.^{\circledR}\right)$ and diflufenican + isoproturon (Panther ${ }^{\mathbb{B}}$ ). All the applied treatments increased the weight of 1000-grains over the weedy check treatment in both seasons of 2007 and 2008.
\end{abstract}

\section{INTRODUCTION}

Wheat (Triticum aestivum L.) ranks the second crop after maize in the world cereal outputs and it is a staple food for billions of people all over the world. Wheat is the most important among food cereals in Egypt. The flour of wheat is the major dietary for people and its straw is used as a major animal feed. There are many factors responsible for low yield. One of the major causes of low yield is weed infestation.

Weeds reduce the crop yield and deteriorate the quality of the product which reflected on the market value of wheat. Weed management increases the cost of production and thus it is necessary to devise such methods which could reduce not only the cost of production but also save time and labor. One of the methods is chemical weed control, which is one of the recent origins that are being emphasized in modern agriculture (Taj et al., 1986).

Donald and Easten (1995) reported that weeds are considered to be a serious problem in wheat in Egypt. Weeds compete with wheat plants for soil moisture, water and sun light and nutrients. This competation lead to grain yield reduction estimated by $7 \%$ (Shah et al. 2005), 52\% (Khan et al., 2003), 92\% (Tiwari and Parihar, 1997), 42-56\% (Abdel-Hamid et al., 1998), $41 \%$ (Abouziena et al., 2008). In serious cases complete crop failure may be happened (Abdul-Khaliq and Imran, 2003).

Competition with weeds decreased both the yield and the content of grain protein of wheat. Most agricultural weed problems however require the destruction of weeds without simultaneous damage to the crop amongest which the weeds are growing. Herbicides are used in agriculture to remove weeds that would otherwise compete with the crop.

Broadleaved that infesting wheat fields represent an increasing problem in many growing areas in Egypt. Among the most troublesome weeds are beet (Beta vulgaris), nettleleaf goosefoot (Chenopodium murale) and toothed bur clover (Medicago hispida). To obtain maximum wheat yield, weeds should be controlled at proper time in right manner. It is very important to determine the critical period of weed-crop competition to plan an effective weed control method (Chaudhary et al., 2008).

The availability of selective herbicides during the last 30 years has enabled farmers to grow high-yielding wheat varieties bred successfully to achieve optimal yields in weed-free conditions (Powles et al., 1997). Nevertheless, full-season control of broadleaved weeds is difficult to obtain. Some weeds escape control with the broadleaved herbicides because of their resistance to herbicides and the change in weed flora due to the repeated applications of these herbicides (Zand, 2004).

Therefore, the present study was directed to evaluate four herbicides namely: [bromoxynil-octanoate $\left(\right.$ Brominal $^{\circledR} 24 \%$ EC), tribenuron-methyl (Granstar ${ }^{\circledR}$ $75 \%$ DF), diflufenican+isoproturon (Panther ${ }^{\circledR} 55 \%$ SC) and florasulam+flumetsulam (Derby ${ }^{\circledR} 17.5 \%$ SC) ] against the most important wheat weeds. Furthermore, their effect on yield was studied.

\section{MATERIALS AND METHODS}

2.1. Herbicides

The common, chemical and trade names, as well as formulation and the rates of the herbicides are shown in Table (1). 
Table 1. Common, chemical, Trade names, formulation and the rates of post-emergence herbicides application during the seasons of 2007 and 2008

\begin{tabular}{|c|c|c|c|c|}
\hline $\begin{array}{l}\text { Common } \\
\text { name }\end{array}$ & Chemical name & $\begin{array}{l}\text { Trade } \\
\text { name }\end{array}$ & $\underset{n}{\text { Formulatio }}$ & $\begin{array}{l}\text { Appl. Rate } \\
\text { /fed. }\end{array}$ \\
\hline $\begin{array}{l}\text { Bromoxynil- } \\
\text { octanoate }\end{array}$ & 2,6-dibromo-4-cyanophenyl octanoate & Brominal $^{\circledR}$ & EC $24 \%$ & $1000 \mathrm{ml}$ \\
\hline $\begin{array}{l}\text { Diflufenican } \\
\qquad+ \\
\text { isoproturon }\end{array}$ & $\begin{array}{l}N \text {-(2,4-difluorophenyl)-2-[3-(trifluoro } \\
\text { methyl)phenoxy]-3-pyridine carboxamide } \\
N, N \text {-dimethyl- } N \text {-[4-(1-methylethyl) phenyl]urea }\end{array}$ & Panther ${ }^{\circledR}$ & SC $55 \%$ & $600 \mathrm{ml}$ \\
\hline $\begin{array}{l}\text { Tribenuron- } \\
\text { methyl }\end{array}$ & $\begin{array}{l}\text { Methyl-2-[[[[(4-methoxy-6-methyl-1,3, 5-triazin-2- } \\
\text { yl)methyl-amino]carbonyl }] \\
\text { amino }] \text { sulfonyl }] \text { benzoate }\end{array}$ & Granstar $^{\circledR}$ & DF $75 \%$ & $8 \mathrm{~g}$ \\
\hline $\begin{array}{c}\text { Florasulam } \\
+\end{array}$ & $\begin{array}{l}N \text {-(2,6-difluorophenyl)-8-fluoro-5- } \\
\text { methoxy[1,2,4]triazolo[1,5-c]-pyrimidine-2- } \\
\text { sulfonamide }\end{array}$ & Derby ${ }^{\circledR}$ & SC $17.5 \%$ & $30 \mathrm{ml}$ \\
\hline flumetsulam & $\begin{array}{l}N \text {-(2,6-difluoro-phenyl)-5-methyl[1,2,4]- } \\
\text { triazolo[1,5-a]pyrimidine-2-sulfonamide }\end{array}$ & & & \\
\hline
\end{tabular}

\subsection{Agricultural practices}

Agricultural practices (soil preparation, tillage, irrigation and fertilization) were applied according to Egyptian Ministry of Agriculture recommendations. Sowing process was done on the second week of November in both seasons at recommended rates at a research experimental farm. Then, the post-emergence herbicide treatments were applied after 30 days from sowing (stage 2 to 4 leaves) with a knapsack sprayer (CP3) at a volume rate of $200 \mathrm{l} / \mathrm{fed}$ as indicated in Table 1.

\subsection{Weed assessments}

From each experimental plot, one square meter (1 $\mathrm{m}^{2}$ ) was selected randomly to identify and collect the three selected broad leaved weeds [wild beet (Beta vulgaris), nettleleaf goosefoot (Chenopodium murale) and toothed bur clover (Medicago hispida)]. The number of these selected weeds/ $\mathrm{m}^{2}$ was recorded 7,14 and 21 days post-spraying. The reduction percentage of weed numbers ( $\mathrm{R} \%$ ) was calculated according to the following equation:

$\mathrm{R} \%=\underline{\text { No. of weeds in the weedy check }- \text { No. of weeds in the treatmen } \mathrm{t}} * 100$

$$
\text { No. of weeds in the weedy check }
$$

\subsection{Determination of yield}

At harvest time, plants in an area of $1 \mathrm{~m}^{2}$ were collected from each experimental plot to determine the grain yield of wheat (g). The yield expressed as ardab/feddan was calculated. Also, 1000 grains of those wheat plants grown in each plot were counted and weighted $(\mathrm{g})$.

\subsection{Statistical analysis}

Data were subjected to the analysis of variance test (ANOVA) as complete randomized block design (CRB). The least significant differences (LSD) at the $5 \%$ level were determined using a computer program (Costat) and Duncan's Multiple Range testes modified by Steel and Torrie (1981) and LSD values were used to compare the average numbers of the all studied characters.

\section{RERSULTS AND DISCUSSION}

\subsection{Weed identification}

Ten weeds belonging to six different families were detected and surveyed in the experimental fields. The prevalent weed species in wheat experimental fields of this running study were the wild beet (Beta vulgaris), nettleleaf goosefoot (Chenopodium murale), toothed bur clover (Medicago hispida), sour grass (Rumex dentatus), spring vetch (Vicia sativa), sow-thistle (Sonthus oleraceus), black mustard (Brassica nigra), wild oast (Afina fatua), darnel (Lolium temulentum) and bermuda grass (Cynodon dactylon).

\subsection{Effect of herbicide application on broad leaved weeds population}

\subsubsection{The wild beet weed (Beta vulgaris)}

The effect of the tested herbicides was evaluated against the most common aboundant weeds. Data in Table (2) illustrate the effect of the evaluated herbicides on the mean numbers and reduction percentages of the wild beet weed in both seasons of 2007 and 2008. The herbicidal effect due to evaluated compounds against 
wild beet weed population was determined under field conditions. Most of the evaluated treatments were found

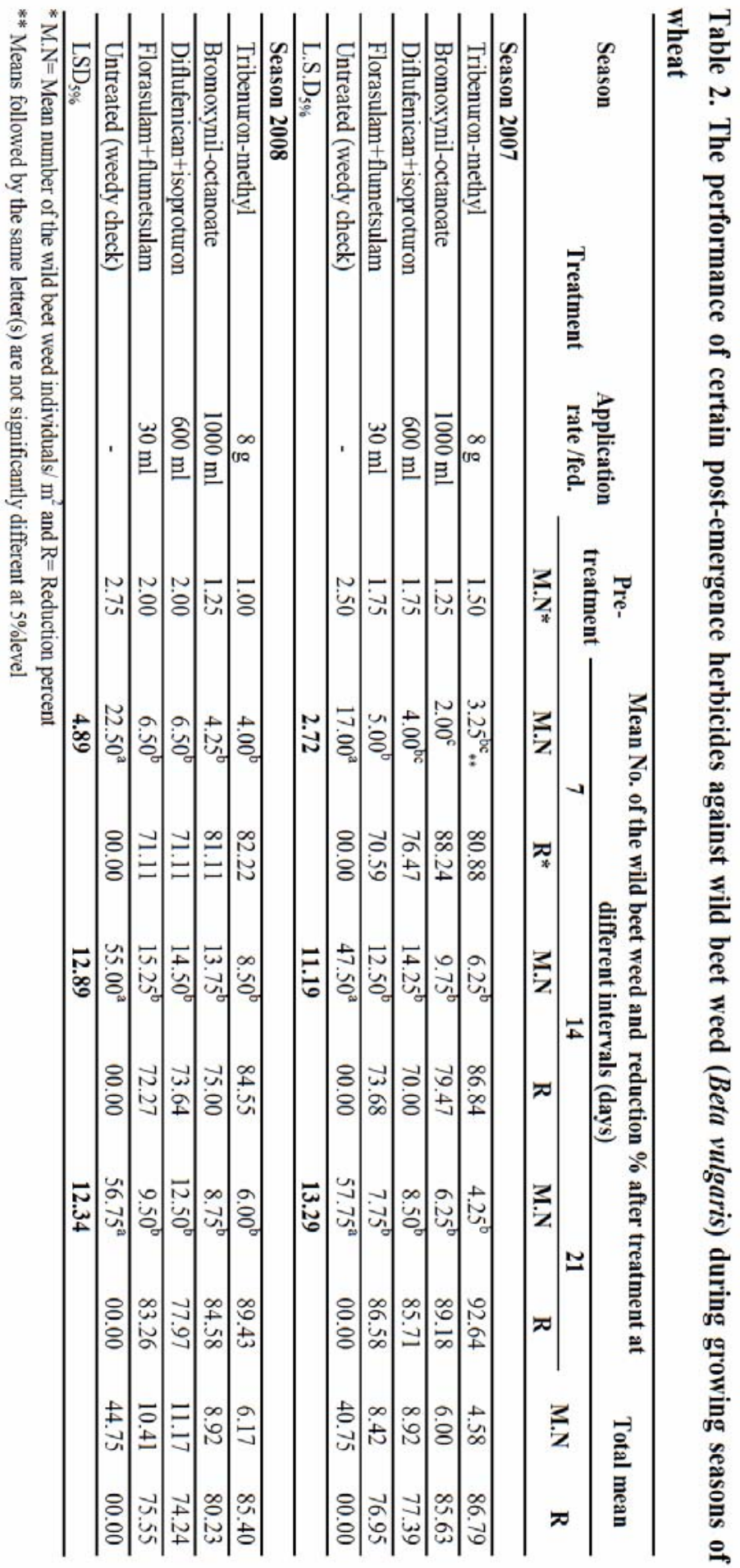


Generally, all the tested herbicides significantly decreased weed population over the weedy check treatment throughout the whole inspection intervals during 2007 and 2008 seasons. In the first season (2007), the general mean of reduction percentages throughout the whole inspection intervals revealed that tribenuron-methyl exhibited the highest mean of reduction estimated by $86.79 \%$, followed by bromoxynil - octanoate $(85.63 \%)$, diflufenican + isoproturon $(77.39 \%)$ and florasulam+flumetsulam (76.95\%).

Regarding the second season of 2008, the general mean of reduction percentages throughout the whole inspection intervals proved that tribenuron-methyl exhibited the highest mean of reduction which estimated by $85.40 \%$, followed by bromoxyniloctanoate $(80.23 \%)$, florasulam+flumetsulam $(75.55 \%)$ and diflufenican+isoproturon (74.24\%).

It was found that there was a relationship between the herbicidal effect of tribenuron-methyl and the postapplication time where the efficacy of this compound (tribenuron-methyl) was increased with the time after application gradually. In the first season, the reduction of this weeds population due to tribenuron-methyl application was $80.88 \%$ after 7 days post-treatment and his reduction percentage increased to $86.84 \%$ after 14 days, then it was increased to $92.64 \%$ after 21 days. In the $2^{\text {nd }}$ season, this trend was assured whereas; the reduction percentages of tribenuron-methyl were estimated by $82.22 \%, 84.55 \%$ and 89.43 after 7,14 and 21 days post-application, respectively. Twenty one days post-treatment was the most effective period for controlling wild beet weed by herbicides tribenuronmethyl and florasulam+flumetsulam, and it is worth to mention that tribenuron-methyl and florasulam+flumetsulam have the same mode of action. There were no significant differences among the applied herbicides against Beta vulgaris and it could be said that it is better for the farmer to choose the cheapist herbicide to reduce the costs of weeds control in case of having a problem of Beta vulgari spreading. From the environment point view, it would be better to choose the more safe and friendly herbicide among those tested compounds.

\subsubsection{The toothed bur clover weed (Medicago hispida)}

The effect of the tested herbicides on the mean numbers and reduction percentages of the toothed bur clover weed in both seasons of 2007 and 2008 was presented in Table (3). Despite, there were no significant differences among treatments sometimes; all herbicides decreased the toothed bur clover weed population significantly over the weedy check in both 2007 and 2008 wheat growing seasons.

The general mean of reduction percentages throughout the whole inspection intervals showed that tribenuron-methyl exhibited the highest mean of reduction that estimated by $89.10 \%$, followed by bromoxynil-octanoate $(87.71 \%)$, florasulam + flumetsulam $(83.53 \%)$ and diflufenican + isoproturon $(82.47 \%)$.

Most of the second season (2008) results had more or less the same trend as that of the first season (2007). It is obvious that the general mean of reduction percentages throughout the whole inspection intervals cleared that tribenuron-methyl exhibited the highest mean reduction that reached $87.30 \%$, followed by bromoxynil-octanoate $(84.36 \%)$, florasulam + flumetsulam $(80.21 \%)$ and diflufenican + isoproturon (76.04\%).

\subsubsection{The nettleleaf goosefoot weed (Chenopodium murale)}

Data in Table (4) represent the effect of the applied herbicides on the mean numbers and reduction percentages of the nettleleaf goosefoot weed during both seasons of 2007 and 2008. The results show that there were no significant differences among the mean numbers of the weed in whole intervals of inspection (7, 14 and 21 days post-application) of the applied treatments through both seasons and all the tested herbicides significantly decreased weed population over the weedy control in both seasons.

According to the general mean reduction percentages throughout the whole inspection intervals (1, 2 and 3 weeks post-treatment) during season 2007 , the most effective reduction was obtained by the application of tribenuron-methyl giving the highest reduction percentage of $91.00 \%$ followed by bromoxynil-octanoate, florasulam + flumetsulam and diflufenican+isoproturon giving reductions of $90.73 \%$, $88.00 \%$ and $82.29 \%$, respectively. The least efficacy was showed by diflufenican+isoproturon compared with the other tested compounds.

Regarding the results of the second season (2008) after one-week post-treatment, the treatments could be arranged due to their efficacy as follows tribenuronmethyl $(78.26 \%)$, bromoxynil-octanoate (69.57\%), florasulam + flumetsulam $(62.31 \%)$ and diflufenican + isoproturon $(56.52 \%)$. According to the mean numbers of the nettleleaf goosefoot individuals $/ \mathrm{m}^{2}$, the highest mean number of the weed was observed in diflufenican + isoproturon treatment $\left(7.50\right.$ weed individuals $\left./ \mathrm{m}^{2}\right)$ indicating less efficacy, while the most efficient one 
was tribenuron-methyl (3.75) showing the superior effect.

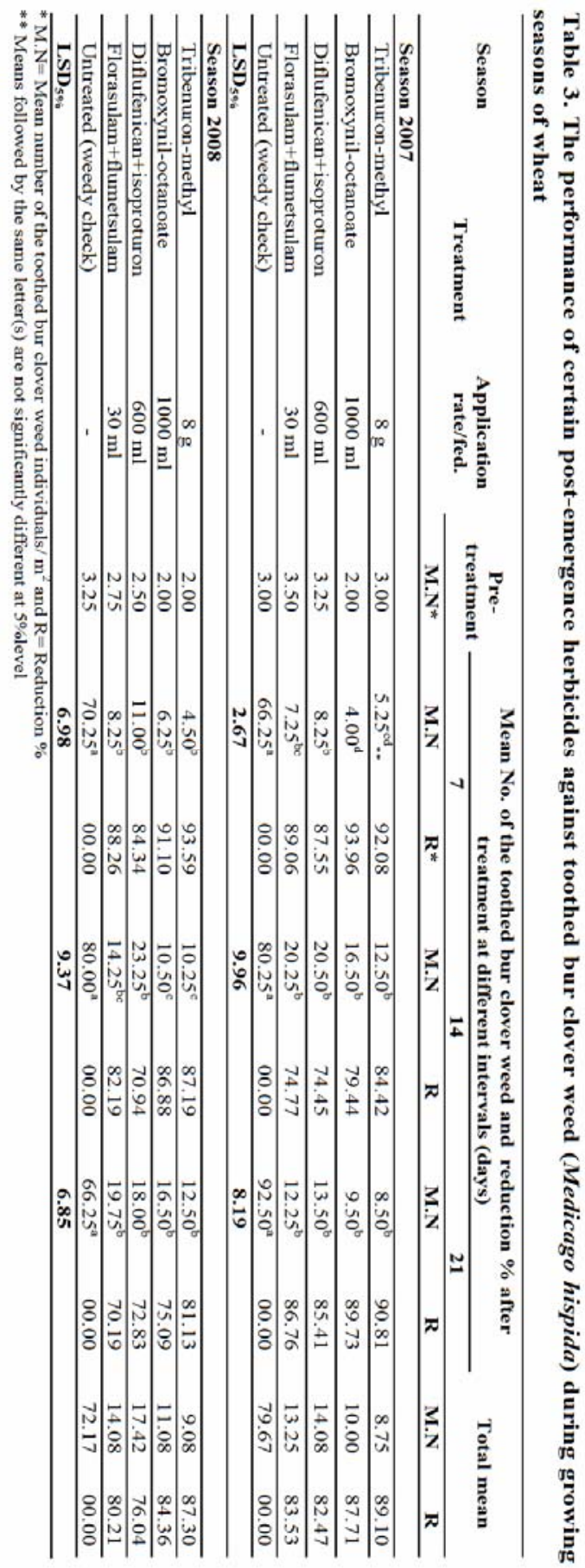




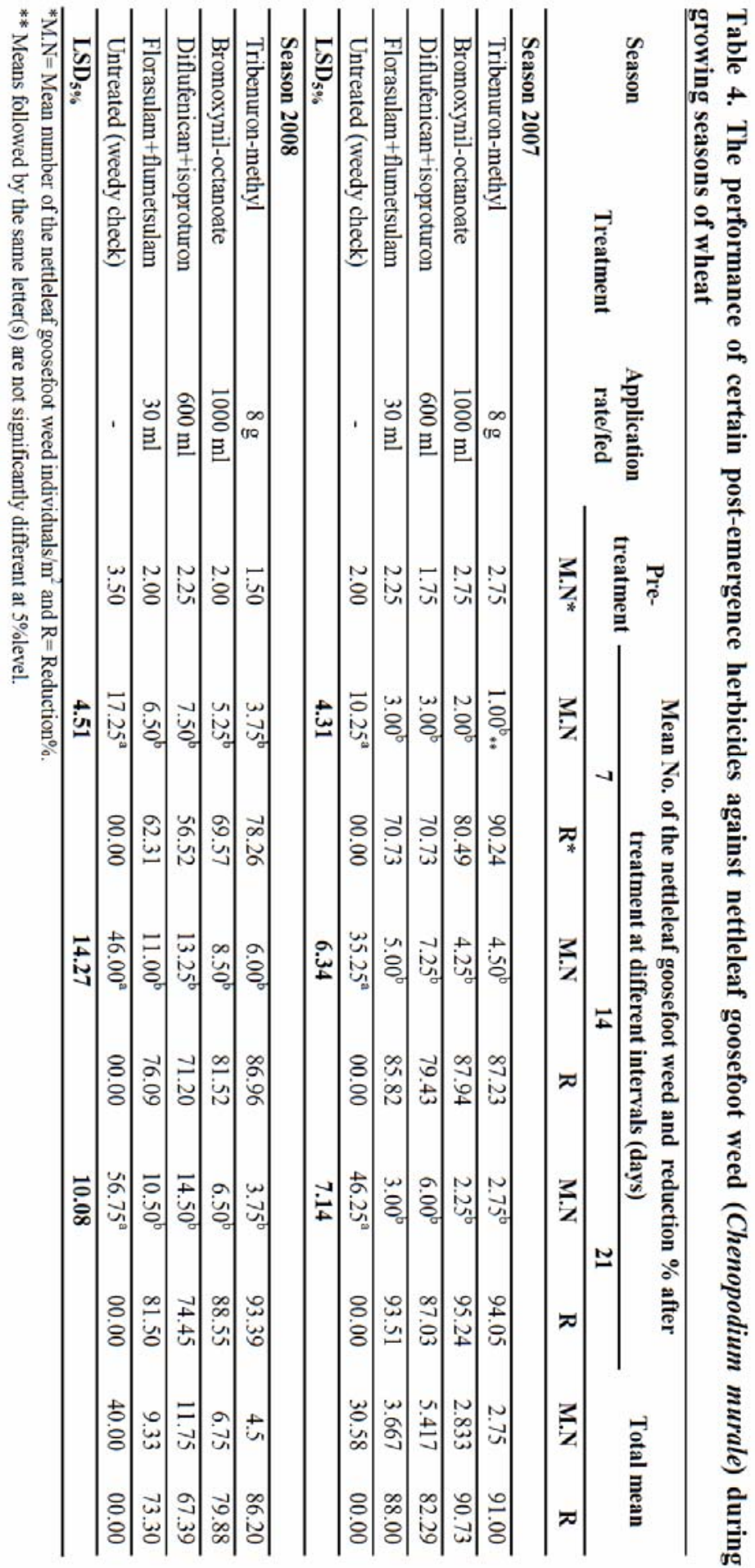


Also, the general mean of reduction percentages throughout the whole inspection intervals $(1,2$ and 3 weeks) post - treatment during the season of 2008 showed that the most effective compound was tribenuron-methyl giving the highest reduction percentage of $86.51 \%$, followed by bromoxynil octanoate, florasulam + flumetsulam and diflufenican + isoproturon which gave reduction percentages of $79.88 \%, 73.30 \%$ and $67.39 \%$, respectively. Diflufenican + isoproturon proved to be the least efficient evaluated compound when it was compared with the other tested compounds against $C$. murale.

Data in Table (5) illustrate the cumulative performance of certain post-emergence herbicides against three weeds; wild beet, toothed bur clover and nettleleaf goosefoot during growing seasons of 2007 and 2008. According the total mean numbers and the general mean reduction percentages of all three tested weeds during both seasons of 2007 and 2008, the most effective reduction was obtained by the application of tribenuron-methyl compound followed by the application of bromoxynil-octanoate.

These results in general are in agreement with those obtained by Sabra et al. (1999) who found that tribenuron-methyl gave $97.3 \%$ reduction of the broad leaved weeds population. Also, they found that Sinal ${ }^{\circledR}$ (Metosulam) recorded 100\% reduction in broad leaved weeds and that compound have the same mode of action as that of tribenuron-methyl as they inhibit acetolactate synthase (ALS).

Also, the presented results are in agreement with those obtained by Fenni et al. (2001) who proved that tribenuron-methyl was the most efficient treatment, as it reduced weed densities by 85 and $88 \%$ at 25 and 51 days, respectively after transplanting.

Kalsi et al. (1998) stated that tribenuron-methyl at $20 \mathrm{~g} /$ ha showed an excellent level of weed control and significantly improved grain yield compared to the control (no weeding) during a two years study. The presented results agreed with those results of ElMetwally and El-Rokiek(2007) who reported that Harmony-extra $^{\circledR}$ (tribenuron-methyl+thifensulfuronmethyl at $24 \mathrm{~g} / \mathrm{fed}$. as active ingredient) which have the same tribenuron-methyl mode of action showed an acceptable control of broad leaved weeds but failed to control completely narrow-leaved weeds. Also, Zand et al. (2007) showed that metsulfuron methyl+sulfosulfuron at $36 \mathrm{~g} / \mathrm{ha}$ is a suitable option for the post-emergence control of the broadleaved and grass weeds in wheat.

For bromoxynil-octanoate, Marwat et al. (2006) recorded a high reduction in weed density $\left(16.20 / \mathrm{m}^{2}\right)$ obtained by its application compared with the high density $\left(142.25 / \mathrm{m}^{2}\right)$ in the weedy control plots.

\subsection{The effect of the tested herbicides on yield of wheat and 1000-grains weight}

\subsubsection{Wheat grain yield}

The effect of the evaluated herbicides on wheat yield during both seasons of 2007 and 2008 are presented in Table 6 . The results indicated that all chemical treatments increased the yield of wheat significantly compared with the weedy check treatment in both seasons of 2007 and 2008.

Data of the first season showed that the application of tribenuron-methyl led to the highest percentage of wheat yield increase estimated by $19.49 \%$ followed by bromoxynil-octanoate, florasulam+flumetsulam and diflufencan+isoproturon that give increases of $13.15 \%$, $8.37 \%$ and $5.14 \%$, respectively. There was a significant difference between tribenuron-methyl and diflufencan+isoproturon. On the other hand, there was no significant difference between bromoxynil-octanoate and florasulam+flumetsulam. The lowest yield was obtained by the application of diflufencan + isoproturon (17.59 ardab/fed.) compared with the other applied herbicides.

The presented data in Table 6 revealed that the results of the $2^{\text {nd }}$ season had the same trend as that of the $1^{\text {st }}$ season. Tribenuron-methyl showed the highest percentage of wheat yield increase estimated by $64.86 \%$ followed by bromoxynil-octanoate, florasulam + flumetsulam and diflufencan + isoproturon that gave $47.60 \%, 41.73 \%$ and $15.57 \%$, respectively. It was found that there were no significant differences between the all applied treatments, however the lowest yield was obtained by diflufencan+isoproturon (12.99 $\mathrm{ardab} / \mathrm{fed}$.).

In fact, there were many factors which decrease wheat yield at an alarming rate. The most essential one is weed population. It obvious that there was a relationship between wheat yield and weed population and as the weeds population increases, the yield decreases. In this respect tribenuron-methyl (Granstar ${ }^{\circledR}$ ) achieved the highest reduction of the broad leaved weeds population in both 2007 and 2008 growing seasons. On the other hand, the least reduction of the population of broad leaved weeds and the least percentage of wheat yield increase in both 2007 and 2008 seasons were obtained by diflufencan+isoproturon (Panter®).

These results are in agreement with those obtained by Zand et al. (2007), Fenni et al. (2001) and Kalsi et al. (1998) who stated that tribenuron-methyl showed the 
highest grain yield compared to the control. Also, Abouziena et al. (2008) observed that in the absence of

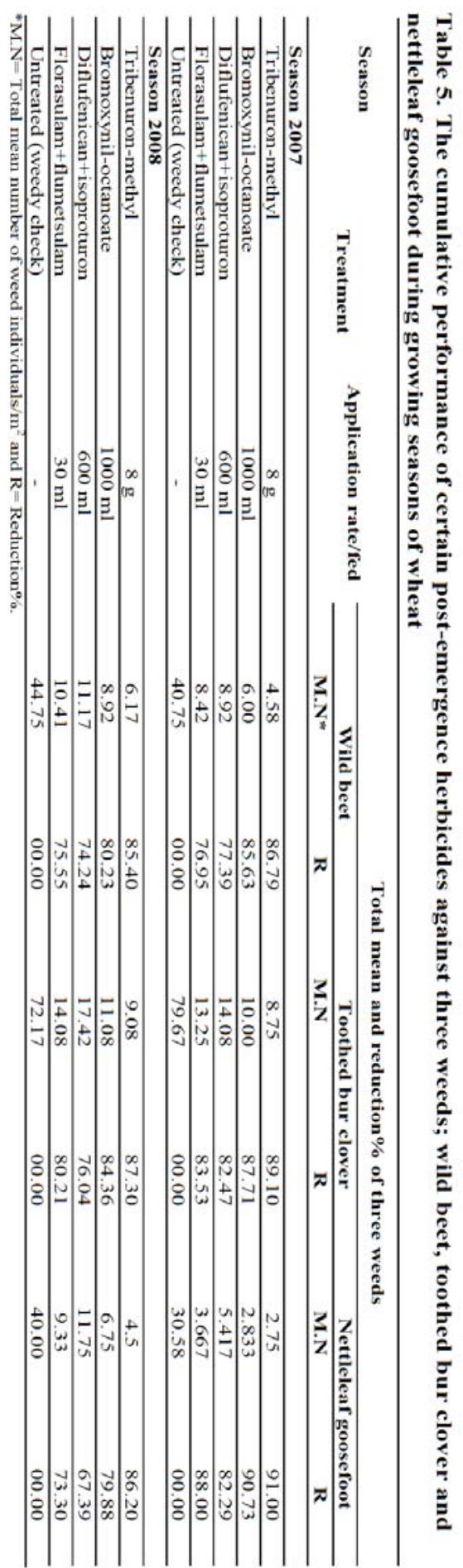




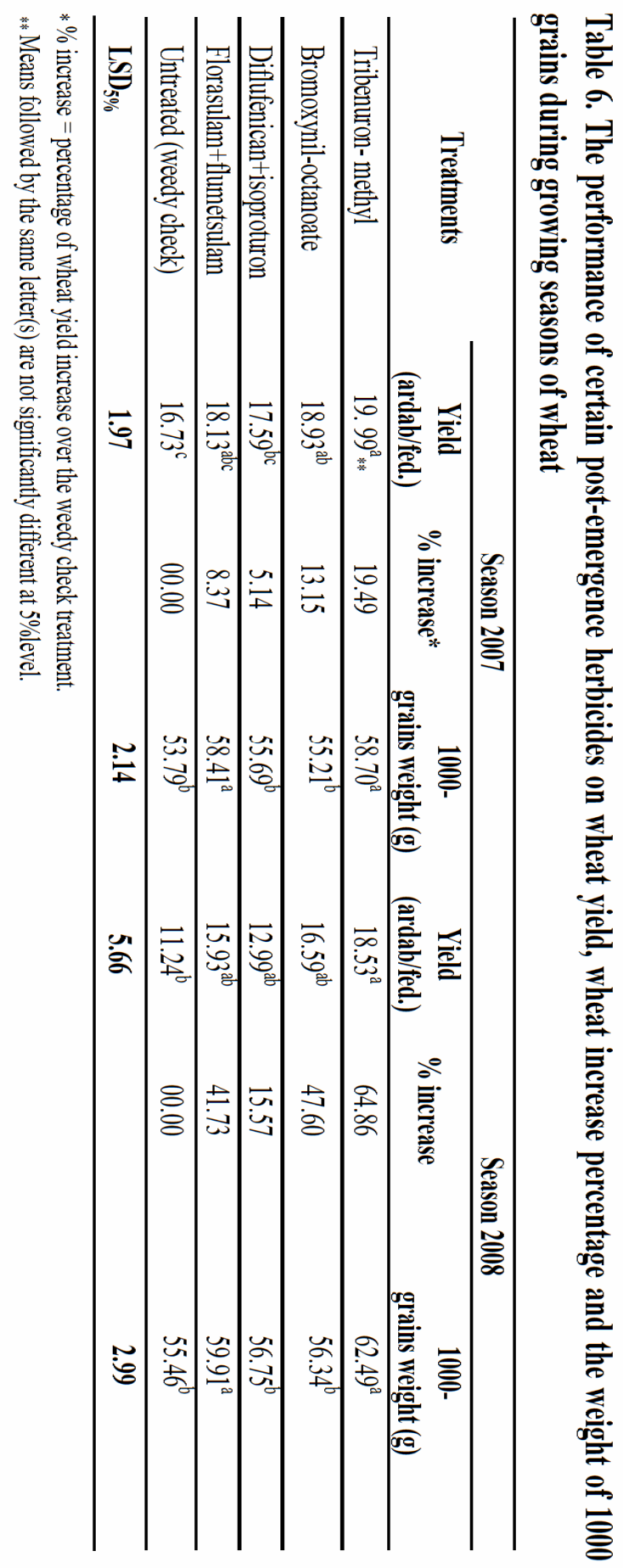


hand weeding and the application of tribenuron-methyl led to a significant increase of grain and biological yields by 51 and $48 \%$ over the un-weeded check.

In both seasons of 2007 and 2008, the weight of 1000- grains was considered for all running chemical treatments compared with the weedy check treatment as shown in Table 6 . The results showed that all treatments increased the weight of 1000-grains over the weedy check treatment in both seasons of 2007 and 2008.

Tribenuron-methyl achieved the high weight of 1000 -grains during the $1^{\text {st }}$ season giving a weight of $58.70 \mathrm{~g} / 1000$-grains, followed by florasulam + flumetsulam (58.41), diflufenican + isoproturon (55.70) and bromoxynil-octanoate $(55.21 \mathrm{~g} / 1000$ grains $)$. Also, the highest weight of 1000 -grains during the $2^{\text {nd }}$ season was recorded by tribenuron-methyl (62.50), followed by florasulam + flumetsulam, diflufenican + isoproturon and bromoxynil-octanoate showing means of 59.91, 56.75 and $56.34 \mathrm{~g}$, respectively.

The wheat yield increase can be due to two factors, the first is caused by increasing the number of yield grains and the other one is due to the increase of the grain weights and its components (straw, carbohydrates, protein and starch). Hence getting rid of weeds would increase the available nitrogen in soil which will led to elevate nitrogen uptake by plants and releases its amount (expressed as protein) in grains and therefore, the increasing of yield components and wheat yield could be achieved.

\section{CONCLUSION}

It could be concluded that the superior effect was achieved by tribenuron-methyl (Granstar ${ }^{\mathbb{B}}$ ) since it is the most effective compound used against the population of all three selected broad leaved weeds (Beta vulgaris, Chenopodium murale and Medicago hispida) giving the highest general mean of reduction percentage of all weeds population and the highest percentage of wheat yield increase, followed by bromoxynil-octanoate $\left(\right.$ Brominal $\left.^{\circledR}\right)$, florasulam + flumetsulam $\left(\right.$ Derby ${ }^{\circledR}$ ) and diflufenican + isoproturon $\left(\right.$ Panter $^{\mathbb{R}}$ ). The application of tribenuron-methyl also increased the weight of 1000-grains as florasulam + flumetsulam did in both seasons of study.

\section{REFERENCES}

Abdel-Hamid, M. M. A.; E. E. Hassanein and S. M. Shebl (1998). Weed/wheat competition in Nile delta. Assiut J. Agric. Sci., 29:105-13.

Abdul-Khaliq, K. A. and M. Imran (2003). Integrated weed management in wheat grown in irrigated areas. Int. J. Agric. Biol., 5(4): 530-532.
Abouziena, H. F.; A. A. Sharara Faida and E. R. El-Desoki (2008). Efficacy of cultivar selectivity and weed control treatments on wheat yield and associated weeds in sandy soils. World J. Agric. Sci., 4 (3): 384-389.

Chaudhary, S. U.; M. Hussain; M. A. Ali and J. Iqbal (2008). Effect of weed competition period on yield and yield components of wheat. J. Agric. Res., 46(1): 47-54.

Donald, A. E. and S. M. Easten (1995). Grain crops. In: Hand Book of Weed Management Systems, (ed. A.E. Smith). Marcel Dekker, Inc. New York, Basal, Hong Kong, pp: 408-411.

El-Metwally, I. M. and K. G. El-Rokiek (2007). Response of wheat plants and accompanied weeds to some new herbicides alone or combined in sequence. Arab Univ. J. Agric. Sci., Ain Shams Univ., Cairo, 15 (2): 513-525.

Fenni, M.; A. N. Shakir and J. Maillet (2001). Comparative efficacy of five herbicides on winter cereal weeds in semiarid region of Algeria. Mededelingen Fac. Landbouwkundige en Toegepaste Biolo. Wetenschappen, Univ. Gent, 66(2b): 791-795.

Kalsi, N. S.; U. S. Walia and L. S. Brar (1998). Control of Rumex spinosus in wheat with sulfonylurea herbicides. J. Res., Punjab Agric. Univ., 35(1/2): 18-21.

Khan, I.; G. Hassan; M. A. Khan and M. I. Khan (2003). Efficacy of some new herbicidal molecules on weed density and yield and yield components of wheat. Pakistan J. Weed Sci. Res., 9(3/4):141-146.

Marwat, K. B.; M. Saeed; B. Gul and Z. Hussain (2006). Performance of different herbicides in wheat (Triticum aestivum L.) under rainfed conditions of Kohat, Pakistan. Pakistan J. Weed Sci. Res., 12(3): 163-168.

Powles, S. B.; C. Preston; I. B. Bryan and A. R. Jutsum (1997). Herbicide resistance: impact and management. Adv. Agron., 58: 57-93.

Sabra, F. S.; F. A. Kassem and M. A. S. Khalifa (1999). Effectiveness of herbicidal treatments against weeds wheat and their action on yield and yield components. J. Pest Cont. Environ. Sci., 7(3): 103-121.

Shah, N. H.; N. H. Ahmed and M. Inamullah (2005). Effect of different methods of weed control on the yield and yield components of wheat. Pak. J. Weed Sci. Res., 11(3-4): $97-$ 101.

Steel, R. G. D. and J. H. Torrie (1981). Principles and procedures of Statistic. Abiometrical approach. 2nd Ed.Mc.Graw.Hill Kogahusha Ltd.pp.633.

Taj, F. H., A. Khattak and T. Jan (1986). Chemical weed control in wheat. Sarhad J. Agric., (2): 15-21.

Tiwari, R. B. and S. S. Parihar (1997). Weed management in wheat (Triticum aestivum). Indian J. Agron., 42(4): 726728.

Zand, E. (2004). Final report of study on weed control spectrum of common broadleaved weed herbicides in wheat fields in Iran. Plant Pest and Disease Res. Institute Press, pp. 47.

Zand, E.; M.A. Baghestani; S. Soufizadeh; R. PourAzar; M. Veysi; N. Bagherani; A. Barjasteh; M. M. Khayami and N. Nezamabadi (2007). Broadleaved weed control in winter wheat (Triticum aestivum L.) with post-emergence herbicides in Iran. Crop Prot., 26(5): 746-752. 


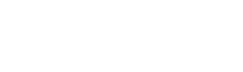

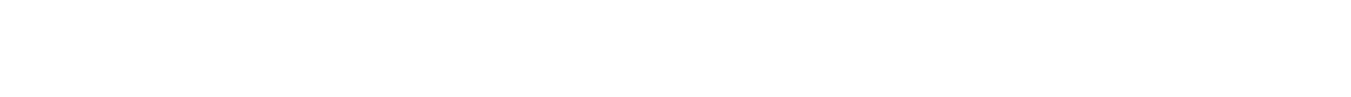

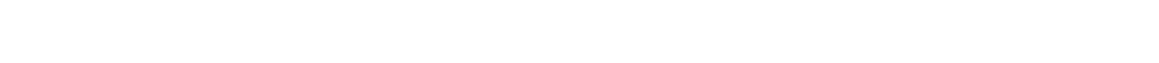

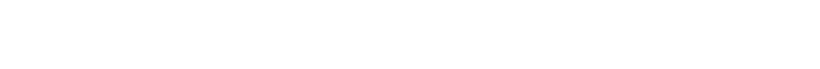

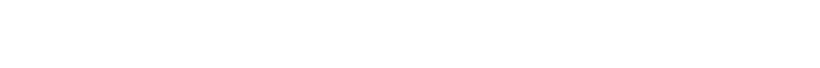

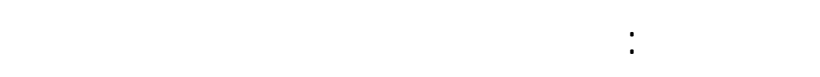

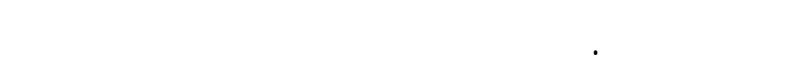

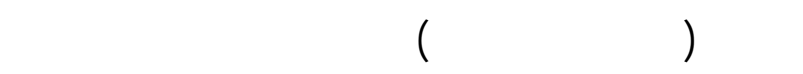

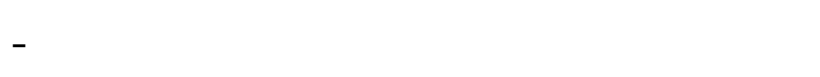

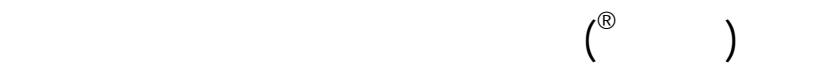

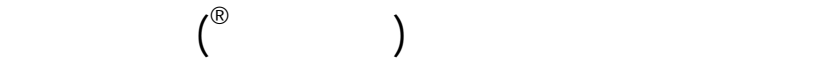

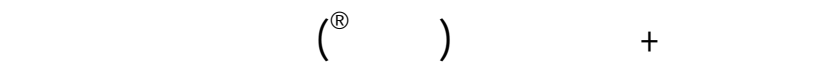

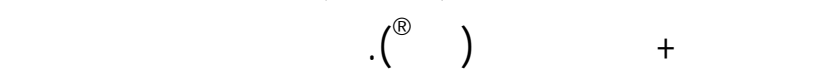

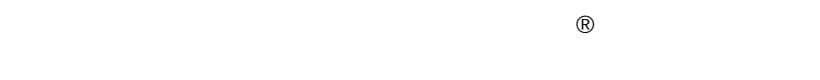

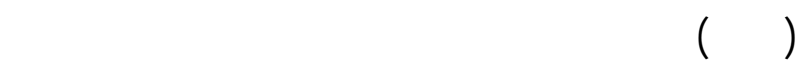

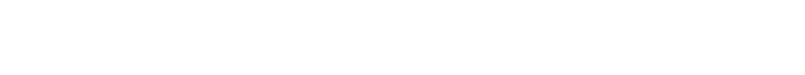

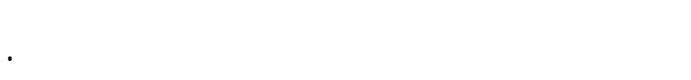

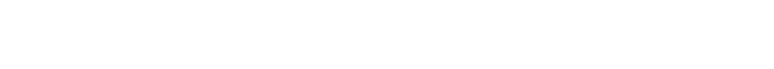

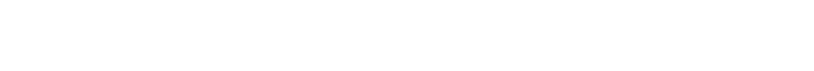
بض مييدات هشبئن القمح عرب ضة الأورق [بروموك سسينل

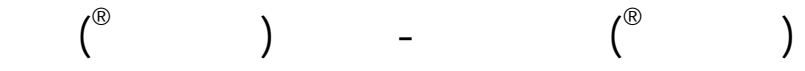

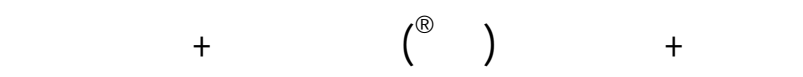

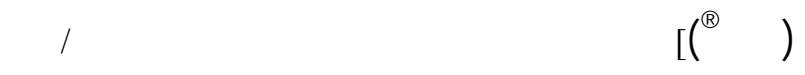

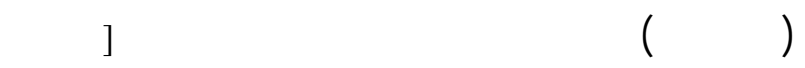

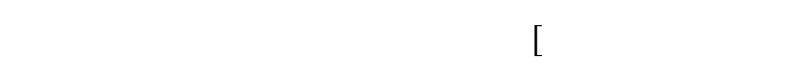

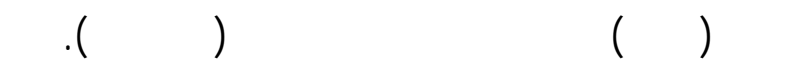

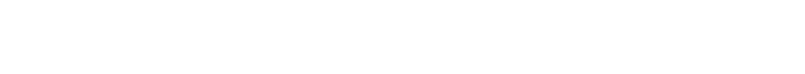

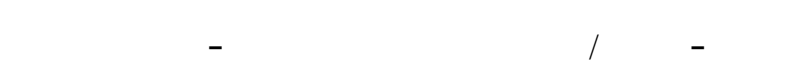

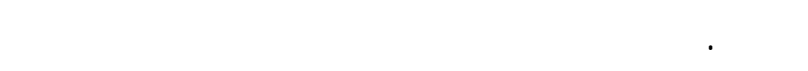

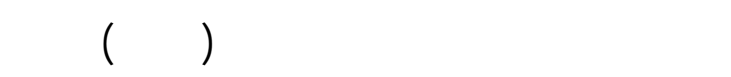

